\title{
INFLUENCE OF INACTIVATED BAKER'S YEAST ON GROWTH POTENTIAL OF RUSSIAN STURGEON ACIPENSER GUELDENSTAEDTII (BRANDT) FINGERLING
}

M. Simon, seemann.sm@gmail.com , Institute of Fisheries NAAS, Kyiv

Yu. Zabytivskyi, yurafish@ukr.net, Lviv Experimental Station of Institute of Fisheries NAAS, Velykyi Lyubin

I. Hrytsyniak, info@if.org.ua, Institute of Fisheries NAAS, Kyiv

Purpose. To analyze the effect of different concentrations of inactivated baker's yeast on the growth rate of Russian sturgeon fingerlings and the associated metabolic processes to establish the optimal concentrations that could be used in the feed composition for the above-mentioned fish, which are cultivated in recirculating aquaculture system (RAS).

Methodology. To achieve the purpose of the work, classical ichtyological and biochemical methods of research were used. So, during the experiment, regular measurements of the mass of fish were performed, mortality was calculated, samples of tissues were selected for further evaluation of the physiological and biochemical status of the organism. The results were processed using variational statistics methods using the standard Microsoft Office Excel package.

Results. The influence of various concentrations of baker's yeast in the composition of feed for Russian sturgeon on its growth and survival rates is demonstrated. In particular, it was found that their concentration of $5 \%$ on the diet within two weeks after transition to exogenous nutrition is optimal.

Scientific novelty. For the first time carried out the analysis of the influence of different concentrations of inactivated baker's yeast, as part of the diet of Russian sturgeon fingerling, on his growth potential.

Practical significance. It has been proved, that inactivated baker's yeast is appropriate to be introduced into the started diet for Russian sturgeon, since it has a positive effect on his digestive system and stimulated growth potential. for fish.

Key words: Russian sturgeon fingerling, inactivated baker's yeast, growth potential, started diet

\section{ВПЛИВ ІНАКТИВОВАНИХ ПЕКАРСЬКИХ ДРІЖДЖІВ НА ПОТЕНЦІАЛ РОСТУ МОЛОДІ РОСІЙСЬКОГО ОСЕТРА ACIPENSER GUELDENSTAEDTII (BRANDT)}

М. Ю. Симон, seemann.sm@gmail.com, Інститут рибного господарства НАAН, м. Київ Ю. М. Забитівський, yurafish@ukr.net, Львівська дослідна станція ІРГ НААН, смт Великий Любінь

I. І. Грициняк, info@if.org.ua, Інститут рибного господарства НАAН, м. Київ

(c) M. Simon, Yu. Zabytivskyi, I. Hrytsyniak, 2018 
Мета. Здійснити аналіз дії різних концентрацій інактивованих пекарських дріжджів на темпи росту молоді російського осетра та пов'язані з иим метаболічні процеси для встановлення оптимальних концентрацій, які могли б бути використані в складі стартових кормів, під час вирощування вищенаведених риб в установках замкненого водопостачання (УЗВ).

Методика. Для досягення мети роботи були використані класичні іхтіологічні та біохімічні методи досліджень. Так, впродовж експерименту регулярно проводили проміри маси риб, підраховували смертність, відбирали проби тканин для подальщої оцінки фізіолого-біохімічного статусу організму. Отримані результати опрацьовували методами варіаційної статистики з допомогою стандартного пакету Microsoft Office Excel.

Результати. Продемонстровано вплив різних концентрацій пекарських дріжджів у складі стартових кормів для російського осетра на показники його росту та виживання. Зокрема виявлено, що їх концентрація обсягом 5\% від раціону впродовж двох тижнів від переходу на екзогенне живлення є оптимальною.

Наукова новизна. Вперше здійснено аналіз впливу різних концентрацій інактивованих пекарських дріжджів у складі раціону молоді російського осетра на потенціал росту останнього.

Практична значимість. Доведено, що інактивовані пекарські дріжджі доцільно вводити в стартові корми для російського осетра, оскільки вони справляють позитивний вплив на його травну систему і стимулюють темпи росту.

Ключові слова: молодь російського осетра, інактивовані пекарські дріжджі, потенціал росту, стартові корми для риб.

\section{PROBLEM STATEMENT AND ANALYSIS OF LAST ACHIEVEMENTS AND PUBLICATIONS}

Intensive development of sturgeon aquaculture with applying recirculating aquaculture system (RAS) provides maximum use of the growing potential all members of this cartilaginous fish family - Acipenseridae [1]. At the same time, it is well-known that one of the biggest problems during the development of life-sustaining sturgeon fingerling is the harmonization of the features their digestive system with starter feeds presented on the market. Fodders for sturgeon, for the most part, in its prescription composition, differ significantly from organisms that are the natural forage base of this age group of fish [2]. As a consequence, feed producers and farmers are confronted with doubtful situations of sturgeon's fingerling active fragmentation growth, with its subsequent prolonged deceleration and the emergence of a number of nutritional disorders caused by the organisn depletion due to inappropriate nutrition. Thus, the greatest losses of the number of Russian sturgeon under conditions of industrial cultivation are registered in the first month of its post-embrionical development. Accordingly, it is relevant to search for the optimal components of start fodder, which would satisfy not only the requirements for the somatic growth of fingerling, but also ensure the harmonious development of all systems of the body, including the formation of the immune system. Recently, inactivated baker's yeast has begun to be used in fish farming as a biologically active additive to the main feed [3]. For example, it is known that their application in this way has a positive effect on the organism as well salt-water and freshwater fish. Research of a wide range of scientists underline the immunomodulatory effect of inactivated baker's yeast and the possibility of their use as a transfer for nutrients, vitamins and minerals [4-8]. The results of the influence of 
iodized yeast on the development and quality of meat and sex products of marketable Siberian sturgeon (Acipenser baeri Brandt, 1869) are sufficiently voluminous, although the author focuses on the effects of iodine, which transfere into the organism and affects its growth rate and biochemical blood parameters [9]. At the same time, the mechanism of action of inactivated baker's yeast on the organism Russian sturgeon fingerling (Acipenser guldenstaedtii Brandt, 1833) requires further research. That is why the work related to the study of their influence on growth rates and associated metabolic processes in organism of Russian sturgeon fingerling, which is cultivated in the RAS, is relevant.

\section{HIGHLIGHT OF THE EARLIER UNRESOLVED PARTS OF THE GENERAL PROBLEM. AIM OF THE STUDY}

Using yeast as well as their products created through biosynthesis in sturgeon aquaculture lasts several decades [3]. The main advantage of this particular group of single-celled fungi in starter fodder is the presence in their composition of a large number of easily accessible oligopeptides, amino and nucleic acids, which are easily digestible by a rapidly growing organism [2]. However, they also contain substances that do not digest or not absorbed, and in certain concentrations, they can even cause contamination with a negative result for the fish organism. Therefore, it is extremely important to carry out an analysis of the effects of various concentrations of inactivated baker's yeast on the growth potential of Russian sturgeon fingerling and related metabolic processes. This will allow them to find out their optimal doses in starter fodder for fish of this species, while growing under the conditions of RAS.

\section{MATERIALS AND METHODS}

Studies have been carried out over the last few years, based on the of the state enterprises Experimental fish farm of Lviv research \& experimental station of the Institute of Fisheries of the National Academy of Agrarian Sciences of Ukraine. The object of research is the Russian sturgeon fingerling, which at the sac fry stage were placed in the RAS. After 10 days of adaptation, it was divided into 3 groups, 500 specimens each in order to further determine the effect of inactivated baker's yeast on productive characteristics.

The basis of food was taken starting sturgeon feed "Initsio Plus" company "Biomar" which production is widely represented in Ukraine market. The abovementioned feed contains $58 \%$ crude protein, $14 \%$ crude fat, $10 \%$ carbohydrates, $0.4 \%$ fiber, $11.5 \%$ ash and $1.7 \%$ total phosphorus.

In the experimental group No. 1 we added to the basic feed $5 \%$ inactivated dry baker's yeast and in the experimental group No. 2-15\%. In the diet of the control group of fish, these single-celled fungi were absent. Yeasts were introduced into the main feed immediately after their inactivation by deep freezing and before feeding the feed to the test specimens. The feeding was carried out six times during the day, taking into account the biorhythms of Russian sturgeon, namely $50 \%$ of the daily ration was set in the morning and evening, and the remeining feed was evenly distributed between four feeding in the afternoon.

The experiment was beginning on the 28th day after leaving the caviar, as soon as 
the feeding of the starting feed was set out and lasted for 14 days. During its conduct, regular measurements of the mass of fish were carried out in order to assess their growth potential, determine mortality, and also sampling tissue for further evaluation of the physiological and biochemical status of the organism.

Every 7 days after the start of the experiment, one gram of fingerling was taken for the purpose of analyzing the activity of digestive enzymes. To do this, they were subjected to anesthesia with $0.2 \%$ solution of the drug "Propisin", and then dissection digestive tract, and subsequently - as linear growth - proximal area of the intestine located after the glandular stomach, and placed the indicated preparations into a deep freezing chamber $\left(-80^{\circ} \mathrm{C}\right)$ liquid nitrogen. After defrosting we carried out homogenization of tissues, centrifugation and in the supernatant was determined activity of major groups of digestive enzymes $-\alpha$-amylase, lipase (steapsin) and trypsin. The activity of amylase was determined by the Jing $\mathrm{Fu}$ method, using 2-chloro4-nitrophenyl- $\alpha$-D-maltotriose at a temperature of $25^{\circ} \mathrm{C}[10]$. The activity of trypsin and lipase was determined by a method which was modified by M. Kamashevsky [11]. The total protein content was determined by the O. H. Lowry method [12]. Conversion of the activity of digestive enzymes was carried out in terms of grams of protein.

Digital data of the obtained results were processed by the methods of variation statistics, using correlation and regression analysis, using computer programs Microsoft Office Excel 2007 and Statistica-6. The analysis of variables is performed on the system of absolute values. The criteria for the analysis of the indicators were their mean value and error $(\mathrm{M} \pm \mathrm{m})$, deviation $(\sigma)$, variability $(\mathrm{Cv})$.

\section{STUDY RESULTS AND THEIR DISCUSSION}

Growth rate indicators for the mass of Russian sturgeon fingerling, which together with the initial feed "Inisio +" fed different concentrations of dry inactivated baker's yeasts, are shown in the diagram (Fig.1)

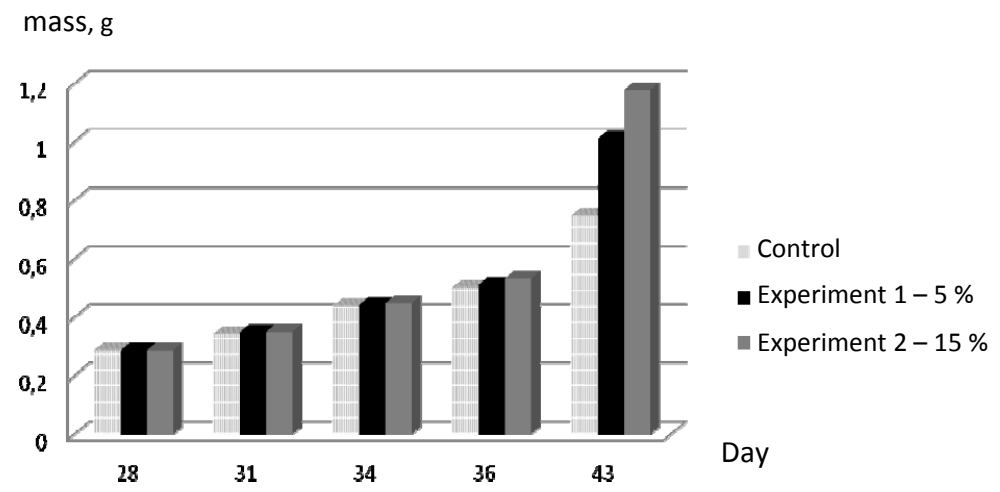

Fig. 1. Growth rate dynamics for the mass of Russian sturgeon fingerling during experimental feeding with 5 and $15 \%$ of dry baker's yeast, respectively, in the starter feed for sturgeon

As can be seen from the figure above, within 36 days after the hatching larvae, the addition of 5\% and 15 yeast in the starter compound feed has a significant effect on the growth rate for the mass of fish. Thus, when feeding in experiment №2 15\% of yeast for

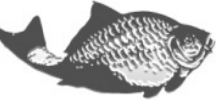


43 days after the hatching, the average weight of experimental specimen prevailed on a $57 \%$ control group of fish. At the same time, the average weight of sturgeon fed $5 \%$ of yeast exceeded the control group by $35 \%$. Dynamically, the mass grew in all groups of fish, but its steady growth was registered in two experimental groups, up to 36 days.

During the first week of the experiment, there were no significant advantages in the growth of young Russian sturgeon in the experimental and control groups, with the exception of the tendency to increase the mass. However, the difference has become apparent already for the second week of experimental feeding. It is obvious that the slow accumulation of vitamins, proteins and nucleic acids in the body gave impetus to metabolic processes, which were expressed in the rapid growth of the mass of fish for 43 days after the hatching.

Thus, from this stage of the experiment, it can be concluded that feeding with dry inactivated baker's yeast at a concentration of 5 and $15 \%$ has a positive effect on fisheries indices of Russian sturgeon fingerling, which cultivation in the RAS, at the end of the 14th day of feeding. In particular, the introduction of this biologically active impurity into the main starter compound feed allows faster growth of fish in the initial stages of ontogenesis.

It should be noted that mortality among Russian sturgeon fingerling at feeding of yeast, from the 28th to the 43rd day of cultivation in RAS, was at zero level in both experimental and control groups.

The analysis of digestive enzymes in the Russian sturgeon fingerling complementary information about the state of the organism in the effects of two concentrations of yeast. Thus, the study of the level of $\alpha$-amylase activity indicates that the content of yeast in feeds in the amount of 5 and $15 \%$ positively affects the activity of hydrolysis of carbohydrates. In particular, the addition of 5\% inactivated baker's yeast to the starter compound feed contributes to an increase in the hydrolysis of carbohydrates by $25 \%$ relative to the control group, however, the probability difference is not registered in the growth rate of fish (Fig. 2). A similar situation was observed for the level of lipase activity (Fig. 3).

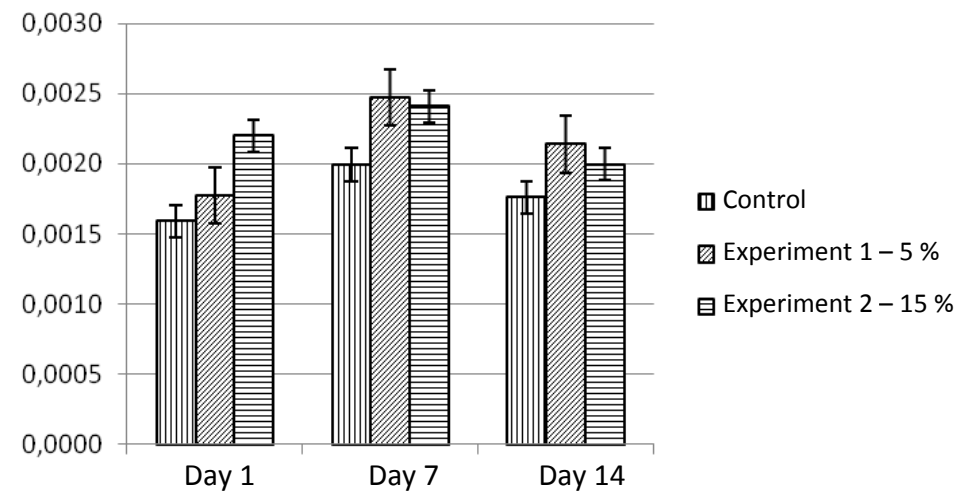

Fig. 2. The level of $\alpha$-amylase activity (U/mg protein) of Russian sturgeon fingerling during experimental feeding with 5 and $15 \%$ of dry baker's yeast, respectively, in the starter feed for sturgeon 


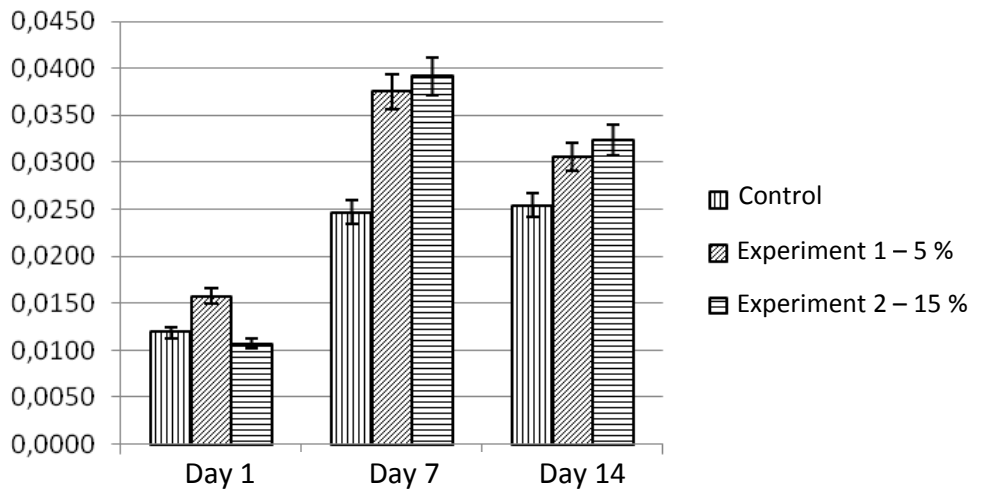

Fig. 3. The level of lipase activity (U/mg protein) of Russian sturgeon fingerling during experimental feeding with 5 and $15 \%$ of dry baker's yeast, respectively, in the starter feed for sturgeon

Thus, with $5 \%$ and $15 \%$ of yeast in the starter feed for sturgeon, lipase activity increases by $51.8 \%$ and $52 \%$, respectively, relative to control results after 7 days of experimental feeding. There is also a slight increase in the activity of trypsin (Fig. 4).

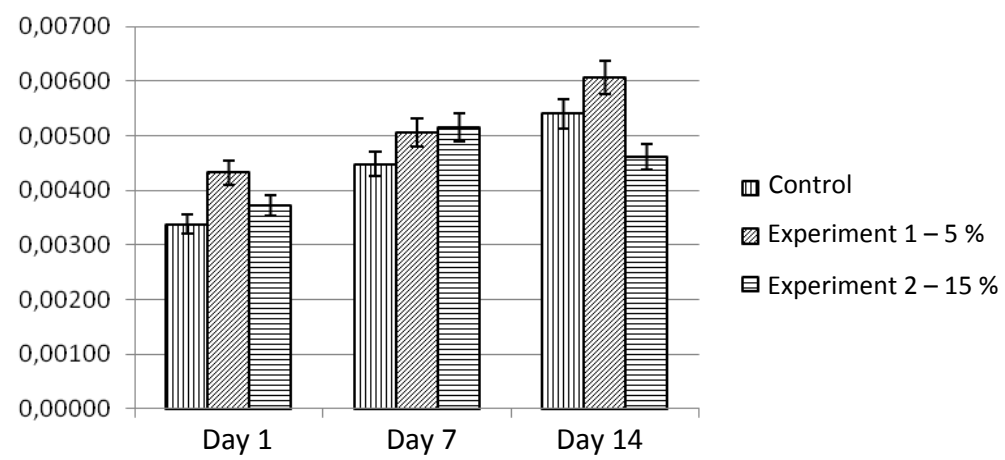

Fig. 4. The level of total trypsin activity of Russian sturgeon fingerling during experimental feeding with 5 and $15 \%$ of dry baker's yeast, respectively, in the starter feed for sturgeon

At 36 days after leaving the larval stage, there is no noticeable tendency to change in growth rates. However, the difference in weight between control and experimental groups is unlikely. However, an increase in the level of activity of digestive enzymes, which was clearly visible at day 7 of our experiment, induced growth potential in the organism of Russian sturgeon. It manifested itself after 14 days, or on the 43rd day of its exit from the larvae stage. As shown in Fig. 1, experimental groups predominate by weight control group of fishes - by $35 \%$ and $57 \%$, respectively. However, figures of the digestive enzymes activity level shown that the highest rates of activity for amylase and trypsin are inherent in the experimental group, that fed 5\% yeast.

Consequently, based on the above data, it can be assumed that the organism more stably uses the growth potential for a low content of yeast in the main feed compound. Further consumption of the same amount of yeast, as in the first two weeks, can lead to digestive system disorders and growth retardation. In particular, as shown in Figure 4, 
sturgeon consumption of $15 \%$ of yeast as part of the starter compound feed affects the reduction of protein hydrolysis. Thus interfering in the processes of building an organism of Russian sturgeon in the first month of his life, when the daily gain of his mass can be up to $10-12 \%$. That is, the lack of activity of trypsin, as a consequence, will slow down the transport mechanisms through the cell membrane, which generally leads to a decrease in growth rates.

\section{CONCLUSION AND PERSPECTIVES OF FURTHER DEVELOPMENT}

The results of our research suggest that dry inactivated baker's yeast has a positive effect on the digestive system of Russian sturgeon and stimulate its growth potential. The optimum dose for introducing into the starting feed is $5 \%$ of the total diet. It is expedient begin to apply it during the period of transition of fingerling to exogenous food and to adhere such diet for two weeks. After that, the amount of yeast in the Russian sturgeon fingerling diet should be reduced to a minimum in order to achieve the immunomodulatory effect, which was investigated by the example of the Beluga (Huso huso Linnaeus, 1758) [13].

\section{BIBLIOGRAPHY}

1. Симон М. Ю. Особливості переходу ранньої молоді осетрових риб (Acipenseridae) на годівлю штучними кормами в УЗВ (огляд) // Рибогосподарська наука України. 2015. №1 (35). С. 106-126.

2. Симон М. Ю. Особливості травлення осетрових видів риб (Acipenseridae) (Огляд) // Рибогосподарська наука України. 2016. № 3(37). С. 123-144.

3. Симон М. Ю. Використання кормових дріжджів у годівлі осетрових видів риб (Acipenseridae) (Огляд) // Рибогосподарська наука України. 2015. № 4(34). С. $100-126$.

4. Effect of dietary nucleotide on antioxidant activity, non-specific immunity, intestinal cytokines, and disease resistance in Nile Tilapia / Rasha M. Reda et al. // Fish \& Shellfish Immunology. 2018. Vol. 80. P. 281-290.

5. Comparative evaluation of Brewer's yeast as a replacement for fishmeal in diets for tilapia (Oreochromis niloticus), reared in clear water or biofloc environments / Nguyen H. et al. // Aquaculture. 2018. Vol. 495. P. 654-660.

6. Efficacy and tolerace of yeast cell wall as an immunostimulant in the diet of Japanese seabass (Lateolabrax japonicas) / Yu H. H. et all. // Aquaculture. 2014. Vol. 432. P. 217-224.

7. Metabolic and bioprocess engineering for production of selenized yeast increased content of seleno-methylselenocysteine / Mapelli V. et al. // Metabolic Engineering. 2011. Vol. 13, iss. 3. P. 282-293.

8. Зубкова Е. Б. Оптимизация состава комбикормов для осетровых рыб с использованием витазара и белковых гидролизатов : автореф. дис. на соискание уч. степени канд.биол. наук : спец. 03.00.10 «Ихтиология». Астрахань, 2001. 21с.

9. Масленников Р. В. Влияние йодированных дрожжей на рост, развитие и товарные качества ленского осетра при выращивании в садках : автореф. дис. на соискание уч. степени канд.с-г. наук : спец. 06.02.08 «Кормопроизводство, кормление сельско-хозяйственных животных и технология кормов». Саратов, 2015. $21 \mathrm{c}$. 
10. Jing Foo A., Bais R. Amylase measurement with 2-chloro-4-nitrophenyl maltotrioside as substrate // Clinica Chimica Acta. 1998. Vol. 272. P. 137-147.

11. Effects of Artemia sp. with essential fatty acids on functional and morfological aspects of the digestive system in Acipenser gueldenstaedtii larvae / Kamaszewski M. et al. // Turkish Journal of Fisheries and Aquatic Sciences. 2014. Vol. 14. P. $1-2$.

12. Protein measurement with the folin phenol reagent / Lowry O. H. et al. // The Journal of Biological Chemistry. 1951. Vol. 193. P. 265-275.

13. Hoseinifar S. H., Mirvaghefi A., Merrifield D. L. The effects of dietary inactive brewer's yeast Saccharomyces cerevisiae var. ellipsoideus on the growth, physiological responses and gut microbiota of juvenile beluga (Huso huso) // Aquaculture. 2011. Vol. 318, iss. 1-2. P. 90-94.

\section{REFERENCES}

1. Symon, M. Yu. (2015). Osoblyvosti perekhodu rannoi molodi osetrovykh ryb (Acipenseridae) na hodivliu shtuchnymy kormamy v UZV (ohliad). Rybohospodarska nauka Ukrainy, 1(35), 106-126.

2. Symon, M. Yu. (2016). Osoblyvosti travlennia osetrovykh vydiv ryb (Acipenseridae) (Ohliad). Rybohospodarska nauka Ukrainy, 3(37), 123-144.

3. Symon, M. Yu. (2015). Vykorystannia kormovykh drizhdzhiv u hodivli osetrovykh vydiv ryb (Acipenseridae) (Ohliad). Rybohospodarska nauka Ukrainy, 4(34), 100126.

4. Rasha, M. R., Khaled, M. S., Rania, M. \& El-Araby, I. E. (2018). Effect of dietary nucleotide on antioxidant activity, non-specific immunity, intestinal cytokines, and disease resistance in Nile Tilapia. Fish \& Shellfish Immunology, 80, 281-290.

5. Nguyen, H. Da, C. T. Lundh T., Lan, T. T. \& Kiessling, A. (2018). Comparative evaluation of Brewer's yeast as a replacement for fishmeal in diets for tilapia (Oreochromis niloticus), reared in clear water or biofloc environments. Aquaculture, 495, 654-660.

6. Yu, H. H., Han, F., Xue, M., Wang, J., Tacon, P., Zheng, Y. H., Wu, X. F. \& Zhang, Y. J.(2014). Efficacy and tolerace of yeast cell wall as an immunostimulant in the diet of Japanese seabass (Lateolabrax japonicas). Aquaculture, 432, $217-224$.

7. Mapelli, V., Hillestrom, P. R., Kapolna, E., Larsen, E. H. \& Olsson, L. (2011). Metabolic and bioprocess engineering for production of selenized yeast increased content of seleno-methylselenocysteine. Metabolic Engineering, 13, 282-293.

8. Zubkova, E. B. (2001). Optimizacija sostava kombikormov dlja osetrovyh ryb s ispol'zovaniem vitazara i belkovyh gidrolizatov. Extended abstract of candidate's thesis. Astrahan'.

9. Maslennikov, R. V. (2015). Vlijanie jodirovannyh drozhzhej na rost, razvitie i tovarnye kachestva lenskogo osetra pri vyrashhivanii v sadkah. Extended abstract of candidate's thesis. Saratov.

10. Jing, Foo A. \& Bais, R. (1998). Amylase measurement with 2-chloro-4-nitrophenyl maltotrioside as substrate. Clinica Chimica Acta, 272, 137-147.

11. Kamaszewski, M., Ostaszewska, T., Prusinska, M., Kolman, R., Chojanacki, M., Zabytivskij, Yu., Jankowska, B. \& Kasprzak, R. (2014). Effects of Artemia sp. with 
essential fatty acids on functional and morfological aspects of the digestive system in Acipenser gueldenstaedtii larvae. Turkish Journal of Fisheries and Aquatic Sciences, 14, 1-2.

12. Lowry, O. H., Rosebrough, N. J., Farr, A. L. \& Randall, R. J. (1951). Protein measurement with the folin phenol reagent. The Journal of Biological Chemistry, 193, 265-275.

13. Hoseinifar, S. H., Mirvaghefi, A. \& Merrifield, D. L. (2011). The effects of dietary inactive brewer's yeast Saccharomyces cerevisiae var. ellipsoideus on the growth, physiological responses and gut microbiota of juvenile beluga (Huso huso). Aquaculture, 318, 90-94.

\section{ВЛИЯНИЕ ИНАКТИВИРОВАННЫХ ПЕКАРСКИХ ДРОЖЖЕЙ НА ПОТЕНЦИАЛ РОСТА МОЛОДИ РУССКОГО ОСЕТРА ACIPENSER GUELDENSTAEDTII (BRANDT)}

М. Ю. Симон, seemann.sm@gmail.com, Институт рыбного хозяйства НАAН, г. Киев

Ю. М. Забытивский, yurafish@ukr.net, Львовская опытная станция ИРХ НАAH, пгт Великий Любень

И. И. Грициняк, info@if.org.ua, Институт рыбного хозяйства НАAН, г. Киев

Цель. Осуществить анализ воздействия различных концентраций инактивированных пекарских дрожжей на темпы роста молоди русского осетра и связанные с этим метаболические процессы для установления оптимальных концентраций, которые могли бы быть использованы в составе стартовых кормов, при выращивании вышеупомянутых рыб в установках замкнутого водоснабжения (УЗВ).

Методика. Для достижения цели работы были использованы классические ихтиологические и биохимические методы исследований. Так, на протяжении эксперимента регулярно проводили промеры массы рыб, вычисляли смертность, отбирали пробы тканей для дальнейшей оценки физиолого-биохимического статуса организма. Полученные результаты обрабатывали методами вариационной статистики с помощью стандартного пакета Microsoft Office Excel.

Результаты. Продемонстрировано влияние различных концентраций пекарских дрожжей в составе стартовых кормов для русского осетра на показатели его роста и выживаемости. В частности установлено, что их концентрация объемом 5\% от рациона в течение двух недель после перехода на экзогенное питание является оптимальной.

Научная новизна. Впервые осуществлен анализ влияния различных концентраций инактивированных пекарских дрожей в составе рациона молоди русского осетра на потенциал роста последнего.

Практическая значимость. Доказано, что инактивированные пекарские дрожжи целесообразно вводить в стартовые корма для русского осетра, поскольку они оказывают положительное влияние на его пищеварительную систему и стимулируют темпы роста.

Ключевые слова: молодь русского осетра, инактивированные пекарские дрожжи, потенциал роста, стартовые корма для рыб. 